\title{
Fisheries and Ocean Currents: A Postmodern Approach
}

\author{
Axel Holmberg* and Sorin Cosofret \\ Canadian University of Nautical Technology, Canada \\ Submission: December 06, 2019; Published: October 16, 2020 \\ Corresponding author: Axel Holmberg, Canadian University of Nautical Technology, Canada
}

Abstract

According to the FAO, a fishery is typically defined in terms of the "people involved, species or type of fish, area of water or seabed, method of fishing, class of boats, purpose of the activities or a combination of the foregoing features". A fishery may involve the capture of wild fish or raising fish through fish farming or aquaculture. Directly or indirectly, the livelihood of over 500 million people in developing countries depends on fisheries and aquaculture. Recent work indicates that ocean currents may have a considerable impact upon the productivity of fisheries, both coastal and inland. In this article, we consider a more postmodern approach to fishery management to reflect the impact of such currents and suggest a movement towards more esoteric methods of fishery management.

\section{Introduction}

Fisheries are harvested for their value (commercial, recreational or subsistence). They can be saltwater or freshwater, wild or farmed. Close to $90 \%$ of the world's fishery catches come from oceans and seas, as opposed to inland waters. These marine catches have remained relatively stable since the mid-nineties (between 80 and 86 million tons). Most marine fisheries are based near the coast. This is not only because harvesting from relatively shallow waters is easier than in the open ocean, but also because fish are much more abundant near the coastal shelf, due to the abundance of nutrients available there from coastal upwelling and land runoff.

However, productive wild fisheries also exist in open oceans, particularly by seamounts, and inland in lakes and rivers. Management of fisheries is of upmost importance to their productivity, and thus the feeding of the population, and is reflected in this wonderful quote, "if you give a man a fish, you feed him for a day, if you teach a man to fish, you feed him for a lifetime". In his underrated and pre-eminent work Trout Fishing in America (1967), Richard Brautigan adopts a more postmodernist approach to fishing. We argue that this largely forgotten approach should be considered as a method of increasing fishery production. We base our study at
Herralanvuolle (Figure 1). This is an understudied location and is easily accessible. We studied fish stocks along six transects.

Postulate 1: There will be more fish stocks in the water than on land

Whilst it is easy for simple laymen to understand that most fish need water to survive (outside of the anomalous work done at Inns mouth (Lovecraft, 1931)), many so-called experts suggest that this is not the case. We argue that fishes need to swim, and so we expect fishes to be in the water [1].

Postulate 2: There are additional factors to consider beyond biological and chemical

Most of the research indicates that fish require biochemical conditions to thrive. We put forward this postulate as it is not this simple, and other, less-well-considered factors are also, in play.

\section{Results}

To investigate postulate 1 , we count the fish stocks along six transects (Figure 1). The results are displayed in Figure 2. From Figure 2, postulate 1 stands, that is, that fish are more prevalent in the water than on the land. However, we observe a shocking rev- 
elation - by fitting a linear regression to this data (R2 $=0.7656$ ), fish can also exist on land, provided they are within $\sim 6$ meters of the shoreline. This finding makes a mockery of so-called theories of biology - fish are currently defined as "a limbless cold-blooded vertebrate animal with gills and fins living wholly in water", however this is clearly not the case. Even a simple layman can understand that fish once came out of the sea and walked on land, setting the stage for an evolutionary explosion of modern life. This may well be happening again, representing a major event in the history of life on the planet Earth as we know it.

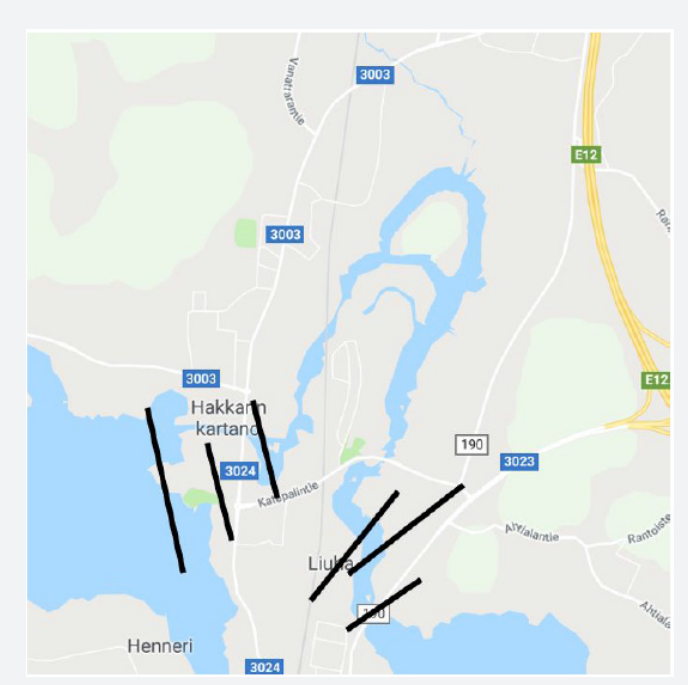

Figure 1: Map of study site. Transects along which fish surveying was undertaken are displayed in black.

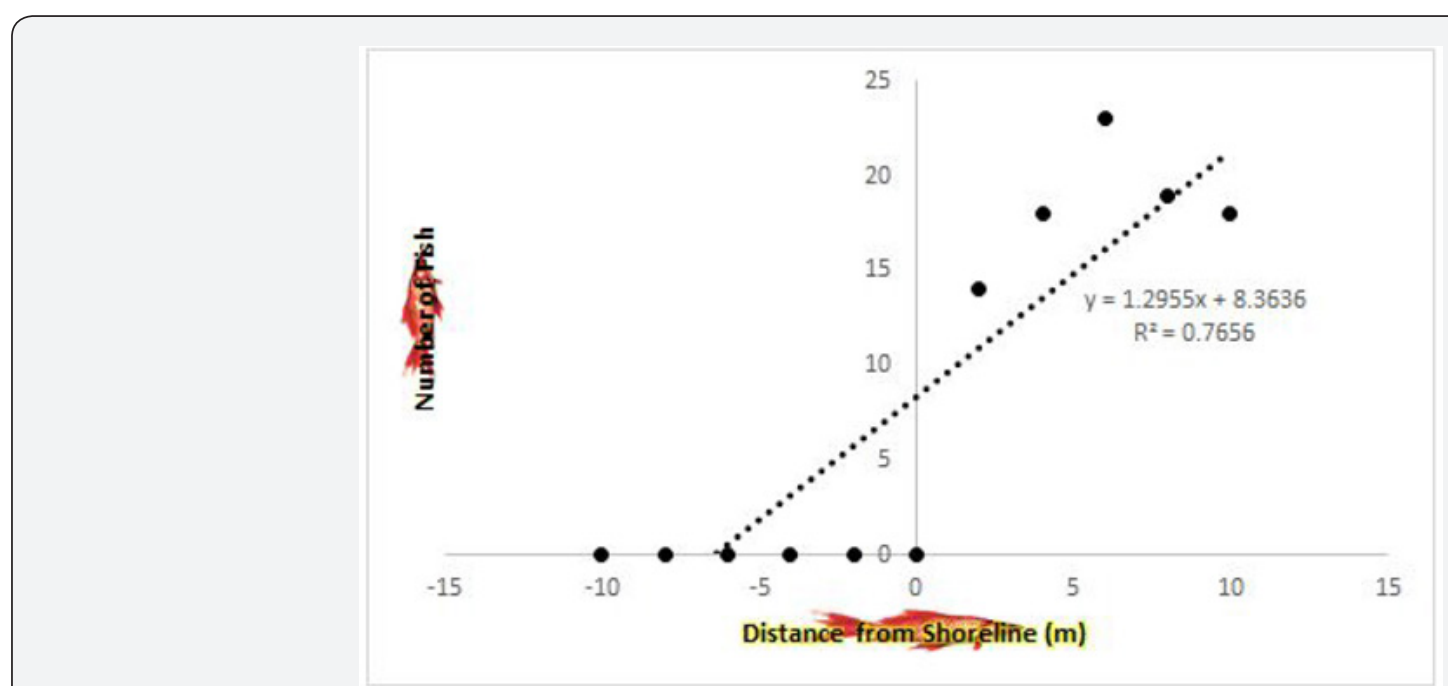

Figure 2: Fish stocks as a function of distance from shoreline $(\mathrm{m})$. A linear regression is fitted to the data.

To investigate postulate 2, we interviewed 200 fish, and asked them to rank the factors that would be most likely to make them reproduce, thus increasing fish stocks. Surprisingly, the most important factor was found to be the fashion sense of the fishery workers. This is unsurprising - even simple laymen can understand why fish would be more likely to swim to the surface to witness such fine fashion. To investigate this on a larger scale, we assess the production of fish from fisheries with reference to the distance of fisheries from the home of fashion, Milan. The results of this are plotted in Figure 3. To optimize fisheries, they should be relocated to northwest Italy, despite what so-called experts say. Additional survey results are displayed in Figures 4 and 5. Fish and ocean life in general need nutrients to survive. To assess trace nutrient concentrations within our study site we used the research vessel RRS Blue Hustler. The results are displayed in Figure 6. Here, we observe that Managed fisheries generally have 
much higher concentrations of essential nutrients than unmanaged fisheries, and so argue that we should move towards a more fishery-dominated global ocean. To meet the rising food demands of the growing population, we will need to grow more fish.

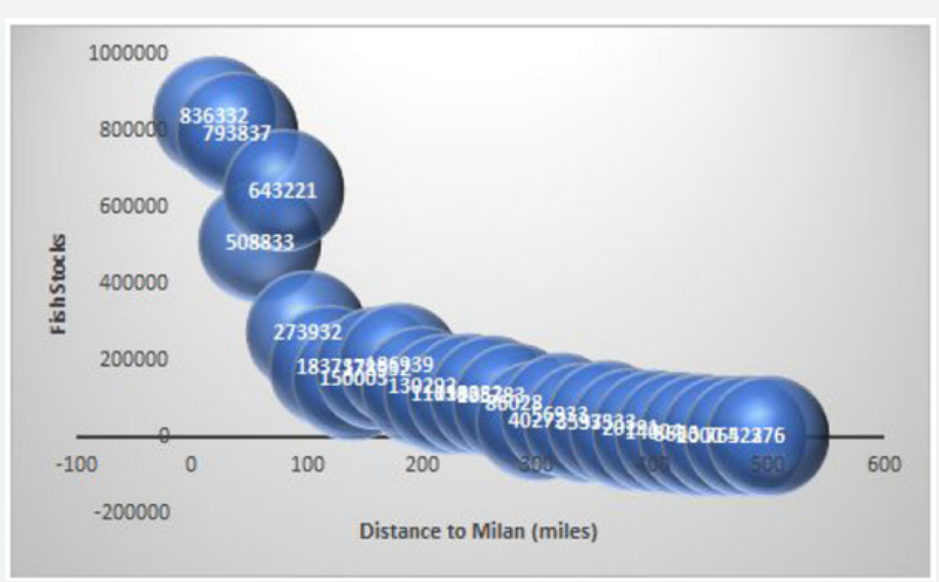

Figure 3: Fishery production as a function of proximity to Milan.

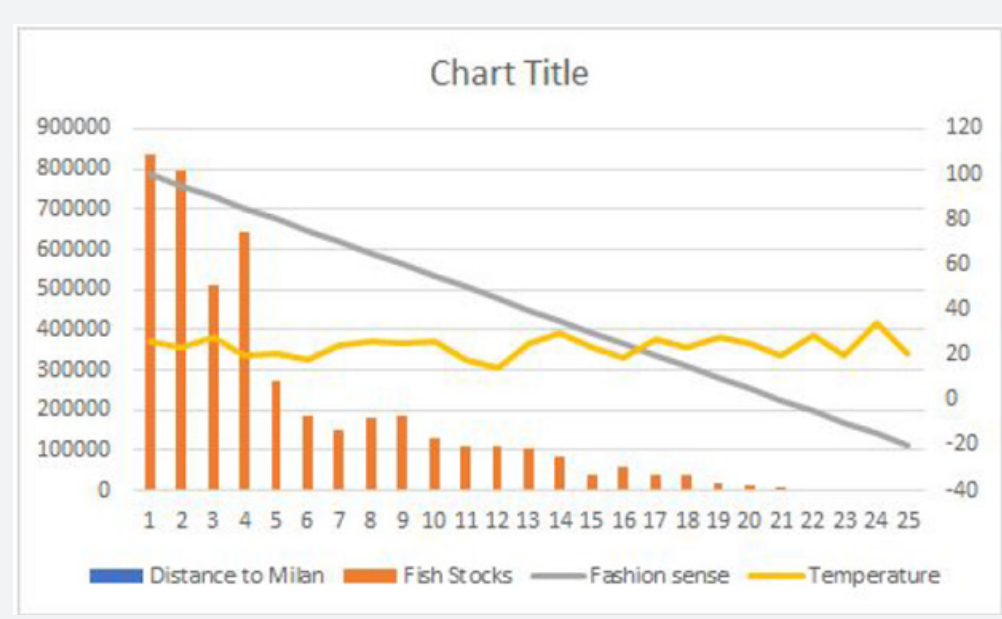

Figure 4: Fishery production as a function of distance to milan, fashion sense (relative) and temperature $\left({ }^{\circ} \mathrm{D}\right)$.

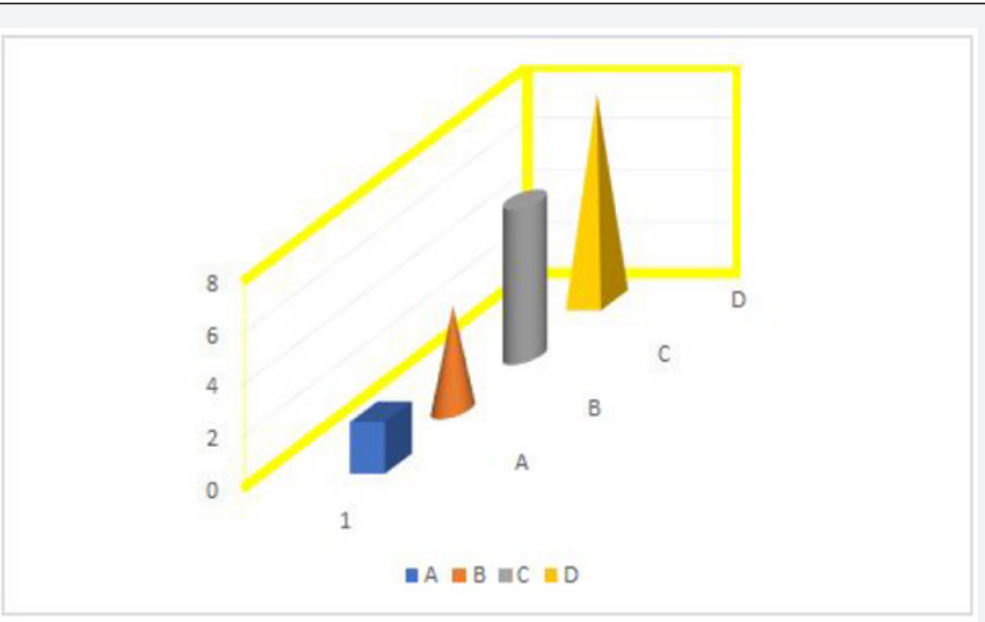

Figure 5: Answers to survey (frequency of reasoning A,B,C,D being given to the question "what is the most important factor for fishery production?", A: temperature, B: salinity, C: ocean currents, D: fashion). 


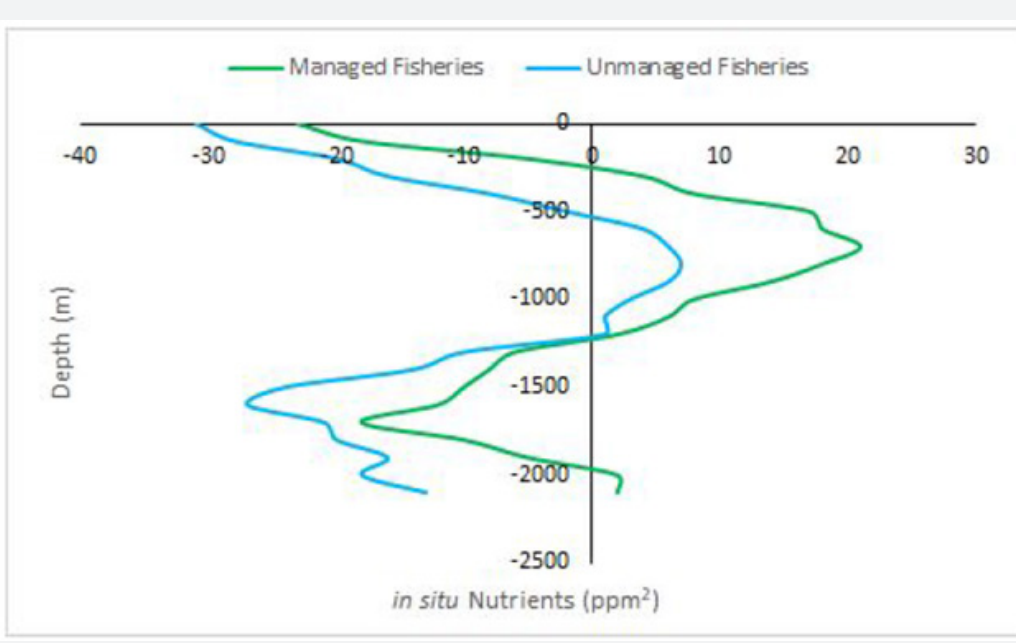

Figure 6: In situ nutrient concentrations for managed versus unmanaged fisheries.

\section{Discussion}

Here we discuss our results. It is clear from these results that a postmodernist approach to fishery management is necessary to provide ample food supply for future generations. Managed fisheries are observed to contain more nutrients required for fish growth. Moreover, fishery productivity increases as distance to fashion decreases [2]. Finally, it is now evident that a step change in evolution is currently undergoing. Whilst it may be difficult to increase the prevalence of fisheries, especially in the north Italy region, if you want the rainbow, you have got to put up with the rain. Do you know which philosopher said that? Dolly Parton. And people say she is just a big pair of tits.

\section{References}

1. Cosofret S (2016) A series of postulates: Neutron Stars.

2. Cosofret S (2015) The Wernham-Hogg approach to differentials.

\section{Your next submission with Juniper Publishers will reach you the below assets}

- Quality Editorial service

- Swift Peer Review

- Reprints availability

- E-prints Service

- Manuscript Podcast for convenient understanding

- Global attainment for your research

- Manuscript accessibility in different formats ( Pdf, E-pub, Full Text, Audio)

- Unceasing customer service

Track the below URL for one-step submission https://juniperpublishers.com/online-submission.php 